\title{
JAM MENGAJAR GURU: TINJAUAN DARI SISI LAIN
}

\author{
Iskandar Agung \\ e-mail: safrusal.1958@gmail.com \\ Puslitjakdikbud, Balitbang - Kemendikbud
}

Jalan Jenderal Sudirman Senayan, Jakarta

\begin{abstract}
Abstrak: Peraturan menuntut guru harus memenuhi beban mengajar minimal 24 jam/minggu dan maksimal 40 jam/minggu. Namun nyatanya untuk kewajiban beban mengajar minimal saja, masih banyak guru yang belum mampu memenuhinya. Padahal, pemenuhan kewajiban minimal merupakan persyaratan agar guru dapat memperoleh Tunjangan Profesi Guru (TPG). Berbagai cara telah diupayakan oleh pihak yang berkepentingan, tetapi persoalan jam mengajar guru masih tetap mencuat ke permukaan. Jika disimak lebih lanjut, upaya pemenuhan ditinjau dari sisi kuantitas, belum mengarah pada kualitasnya. Untuk apa guru dipaksa memenuhi kewajiban jam mengajar, misal dengan mencarinya di sekolah lain, sedang dalam menjalankan tugas di sekolah utama masih mengindikasikan pencapaian hasil belajar peserta didiknya yang kurang memadai? Sewajarnya apabila pemenuhan kewajiban itu tidak hanya ditinjau dari sisi kuantitas, tetapi juga kualitas. Artinya perlu dicarikan alternatif pemenuhan jam mengajar sekaligis berfungsi sebagai pendorong peningkatan kualitas guru, sehingga berdampak positif terhadap peningkatan hasil belajar peserta didiknya. Berkenaan dengan uraian yang disebut terakhir itulah tulisan ini diketengahkan, yakni bermaksud mengemukakan alternatif pemikiran awal mengenai ketentuan jam mengajar guru.
\end{abstract}

Kata-kata kunci: jam mengajar, tunjangan profesi, pengembangan keprofesian berkelanjutan, kinerja

\section{TEACHER'S TEACHING SCHEDULE: A REVIEW FROM ANOTHER PERSPECTIVE}

\begin{abstract}
Regulations require teachers to meet the teaching burden of at minimum 24 hours / week and maximum 40 hours /week. However, in fact, for minimal hour's teaching, still many teachers who have not been able to fulfill it. The fulfillment of minimum obligations is a requirement for teachers to obtain Professional Teacher Allowances (TPG). Various ways have been attempted by interested parties, but the issue of teacher teaching hours is still problems. The fulfillment effort merely in terms of quantity, has not led to quality. For what teachers are forced to fulfill the obligation of teaching hours, e.g. by looking at other schools, being in the duties of the main school still indicates the achievement of the students' inadequate learning outcomes? Naturally if the fulfillment of obligations is not only in terms of quantity, but also quality. This means that the need to find an alternative fulfillment of teaching hours is functioning as a driver to improve the quality of teachers, so that a positive impact on improving student learning outcomes. With regard to the latter description that this paper is presented, that is to say, alternative thinking about the provisions of teaching hours teachers.
\end{abstract}

Keywords: teaching hours, professional allowances, continuing professional development, performance

\section{PENDAHULUAN}

Jam Mengajar Guru (JMG), seperti yang diamanatkan dalam UU No 14 Tahun 2005 dan PP No 74 Tahun 2008 Pasal 15 (3), harus memenuhi beban kewajiban minimal 24 Jam Tatap Muka (JTM) per minggu dan maksimal 40 jam tatap muka per minggu. Namun ketentuan ini ternyata menjadi kendala tersendiri bagi sebagian guru yang tidak dapat memenuhi kewajibannya ini. Secara nasional, pemenuhan jam tatap muka mencatat angka ratarata 17,5 JTM (Ditjen GTK, 2017)1). Meski pihak sekolah berupaya memberi tugas tambahan maupun mengarahkan untuk mencari ke sekolah lainnya, tetapi tidak jarang belum dapat memenuhi beban kewajibannya itu. Hasil penelitian BERMUTU tahun 2013 menunjukkan, sebanyak 12,7 persen dari sampel responden guru yang diteliti menjalankan tugas pembelajaran di sekolah lain, dengan rata-rata perolehan sebanyak 12 JTM per minggu (Puslitjak, 2013).

Dalam Permendiknas No 35 Tahun 2010 misalnya, tertuang sejumlah aspek yang dapat menjadi tugas tambahan untuk memenuhi beban 
kewajiban JTM, antara lain menduduki status sebagai kepala sekolah, wakil kepala sekolah, ketua program keahlian, kepala perpustakaan, wali kelas, dan sebagainya. Namun pemberian tugas tambahan ini sifatnya terbatas, di samping ekuivalensi yang relatif kecil dalam pemberian JTM, sehingga dinilai belum cukup untuk memenuhi beban kewajiban JTM guru yang bersangkutan. Permendikbud No 24 Tahun 2015 memberikan sejumlah jenis tugas tambahan guru, antara lain menjadi wali kelas, membina OSIS, menjadi guru piket, membina ekstrakurikuler, menjadi tutor Paket A/B/C, dan sebagainya, meski hanya berlaku sampai dengan 31 Desember 2016. Lebih lanjut, Permendikbud No 17 Tahun 2016 mengemukakan adanya sejumlah jenis tugas tambahan untuk guru dengan ekuivalensi JTM, seperti yang diperlihatkan dalam tabel 1 berikut ini.

Tabel 1

Jenis Tugas Tambahan Guru dan Ekuivalensinya

\begin{tabular}{ll}
\hline No Jenis tugas tambahan & $\begin{array}{c}\text { JTM } \\
\text { equivalensi }\end{array}$ \\
\hline
\end{tabular}

1 Kepala sekolah 18 JTM

2 Narasumber nasional/instruktur nasional/tim pengembang/ mentor untuk guru pembelajar atau pelaksanaan diklat kurikulum

3 Wakil kepala sekolah (minimal 3 waka untuk SMP)

12 JTM

4 Kepala perpustakaan, kepala lab, ketua program keahlian/ studi, kepala bengkel, kepala unit produksi

5 Guru pembimbing khusus pada sekolah inklusi/terpadu

12 JTM

12 JTM

6 Guru pada sekolah di daerah khusus yang diterapkan oleh Mendikbud

$7 \quad$ Guru pada sekolah yang peserta didiknya kesulitan mengikuti PBM karena kelainan fisik, emosional, mental, sosial, dan/ atau memiliki potensi kecerdasan dan bakat istimewa

8 Guru pada sekolah kecil, sekolah terbuka dan sekolah terintegrasi yang ditetapkan oleh Kemendikbud*)

9 Guru yang dibutuhkan atas dasar pertimbangan kepentingan nasional

(Permendikbud No 17 Tahun 2016)

Tentu tidak semua guru dapat memperoleh tugas tambahan seperti yang tertuang dalam Tabel 1. Oleh karenanya, peraturan menentukan pula adanya jenis tugas tambahan bagi guru dengan ekuivalensi
JTM yang akan diperoleh, antara lain (1) mengajar mata pelajaran yang sama/mata pelajaran lain; (2) menjadi tutor Paket A,B,C, kejuruan/program pendidikan kesetaraan; (3) menjadi guru bina pada sekolah terbuka; (4) menjadi guru pamong pada sekolah terbuka; (5) membina kegiatan ekstrakurikuler wajib Pramuka; (6) melaksanakan pembelajaran perbaikan (remedial teaching); (7) mengelola Taman Bacaan Masyarakat (TBM) milik pribadi, atau milik masyarakat; (8) menjadi Pengelola Kegiatan Keagamaan; (9) mengelola Program Nasional Pemberdayaan Masyarakat (PNPM) mandiri; (10) menjadi guru inti/instruktur/pemandu pada KKG/ MGMP; (11) membina kegiatan mandiri terstruktur bagi peserta didik; serta (12) membina kegiatan lain yang terkait dengan pendidikan masyarakat, misalnya kursus kecantikan, masak, memotong rambut, menjahit.

Segenap hal di atas merupakan upaya pihak kementerian untuk membantu pemenuhan beban kewajiban JTM guru. Namun jika disimak lebih jauh, upaya pemenuhan itu lebih bersifat kuantitatif, dalam arti digunakan untuk memenuhi beban kewajiban dari sisi jumlah JTM guru. Sebaliknya kurang ditinjau dari sudut lainnya, yakni sebagai upaya untuk memotivasi, menstimulir, atau mendorong diri guru agar meningkatkan kualitas pengembangan profesionalisme kerja, kinerja, hasil belajar, dan seterusnya. Lalu apa gunanya berkutat dengan persoalan kuantitatif, apabila tidak memiliki efek yang positif terhadap peningkatan kualitas guru dan hasil belajar peserta didik/siswa? Secara kuantitatif, pemenuhan minimal 24 JTM guru per minggu atau maksimal 40 JTM per minggu hanya untuk memenuhi ketentuan yang ada dan persyaratan untuk memperoleh Tunjangan Profesi Guru (TPG), tetapi tidak terkait dengan upaya peningkatan kualitas guru. Perlu ada pemikiran bagaimana pemenuhan JTM ini bukan sekedar memenuhi jumlah beban kewajiban baru, tetapi berhimpit dengan upaya meningkatkan kompetensi dan profesionalisme kerja, kinerja, hasil belajar siswa, keterlibatan dalam penguatan pendidikan karakter, kemampuan melaksanakan PTK, dan seterusnya.

Berkenaan dengan yang terakhir itulah tulisan ini diketengahkan, yakni bermaksud mengemukakan satu alternatif pemikiran mengenai beban jam mengajar guru. Tulisan berisikan pemikiran awal mengenai pemenuhan jam mengajar guru tinjauan dari sisi lain, dengan berupaya memasukkan unsur/ aspek Pengembangan Keprofesian Berkelanjutan (PKB), kinerja, hasil belajar, penguatan pendidikan 
karakter, penelitian tindakan kelas, tugas tambahan, dan jam mengajar riil. Pemikiran yang diajukan akan mengarahkan pada pemenuhan jam mengajar guru, dan sekaligus memotivasi dan mendorong guru untuk mencapai perilaku pembelajaran yang terus meningkat dari waktu ke waktu.

Peraturan mensyaratkan guru diwajibkan memenuhi beban kerja 24 JTM per minggu atau maksimal 40 JTM per minggu, seperti tertuang dalam UU No 14 Tahun 2005 dan PP No 74 Tahun 2008 Pasal 15 (3). Kenyataannya, masih banyak guru yang belum memenuhi kewajiban tersebut, dan bahkan menghadapi kesulitan tertentu, diantaranya (a) ketidakmungkinan mencari dengan cara mengajar di sekolah lain karena lokasinya yang relatif jauh; (b) tidak diperbolehkan oleh pihak sekolah atau yayasan untuk sekolah swasta; dan (c) sekolah yang ada di sekitar yang sudah memiliki jumlah guru berlebih sehingga tidak dapat menerima guru dari sekolah lain. Di sejumlah daerah memang terkesan guru-gurunya telah mampu memenuhi kewajiban jam mengajar, tetapi hal tersebut disebabkan oleh banyaknya guru yang telah memasuki masa pensiun, sehingga pemerintah daerah setempat mengharuskan guru-guru yang ada untuk mengajar double shift atau mengisi jam mata pelajaran di sekolah lainnya.

Terlepas dari itu semua, upaya yang dilakukan selama ini, antara lain dengan memperluas tugas tambahan guru, baru menekankan pemenuhan jam mengajar guru dari sisi kuantitas. Belum ada pemikiran, bagaimana pemenuhan beban kewajiban guru terkait pula dengan upaya meningkatkan kompetensi, kinerja guru, dan lain-lainnya. Pemenuhan dari sisi kuantitas hanya menuang masalah, terutama dari pencapaian hasil belajar. Guru yang tergolong kurang baik dan mencapai hasil belajar yang kurang baik bagi siswanya, apabila mengajar di sekolah lain hanya cenderung menularkan pencapaian hasil belajar siswa yang kurang baik pula. Perlu dipikirkan, selayaknya pemenuhan jam mengajar terkait dengan upaya meningkatkan kualitas guru, dalam arti pengembangan pemenuhan jam mengajar sekaligus berperan sebagai mekanisme pengendali bagi guru untuk meningkatkan kompetensi, profesionalisme, kinerja, dan pencapaian hasil belajar siswa.

Simak saja, dalam UU No 14 Tahun 2005 mensyaratkan guru harus kompeten dan profesional. Kompetensi yang dimaksud merupakan seperangkat pengetahuan, keterampilan, dan perilaku yang harus dimiliki, dihayati, dikuasai, dan diaktualisasikan oleh guru dalam melaksanakan tugas keprofesionalan.
Ada 4 (empat) komponen kompetensi yang harus dipenuhi oleh guru, yakni (1) kompetensi pedagogis; (2) kompetensi profesional; (3) kompetensi sosial; dan (4) kompetensi kepribadian (Permendiknas No 16 Tahun 2007). Berdasarkan hasil Uji Kompetensi Guru (UKG) yang dilakukan Direktorat Jenderal Guru dan Tenaga Kependidikan, Kementerian Pendidikan dan Kebudayaan, cenderung memperlihatkan kondisi kompetensi guru yang kurang memuaskan. Hasil UKG tahun 2015 (Ditjen GTK, 2015) memperlihatkan pencapaian nilai rata-rata kompetensi pedagogik dan profesional guru sebesar 53,05 berada di bawah ketetapan Standar Kompetensi Minimal (SKM) sebesar 55.

Dari sisi kompetensi sosial dan kepribadian guru, penelitian menunjukkan hal yang sama, yakni adanya kondisi yang masih kurang memuaskan terhadap kedua komponen kompetensi tersebut. Dalam penilaian skala 1 - 5 dari sangat tidak memuaskan sampai dengan sangat memuaskan, kondisi kompetensi sosial berada pada posisi angka 2,70 dan kompetensi kepribadian pada posisi angka 2,73 (Agung, 2016). Kondisi kompetensi guru memang memprihatinkan, dan diduga menjadi penyebab hasil pendidikan peserta didik yang masih belum memuaskan (Agung, 2017).

Pihak Ditjen GTK - Kemendikbud mulai tahun 2016 berupaya meningkatkan kompetensi guru, dengan harapan di tahun 2019 nanti telah mencapai kondisi kompetensi dengan angka rata-rata 80. Untuk itu dilakukan pembinaan guru melalui program Guru Pembelajar berupa Program Peningkatan Kompetensi Moda Tatap Muka, Dalam Jaringan (Daring), dan Daring Kombinasi (Ditjen GTK, 2016). Program Peningkatan Kompetensi Guru Pembelajar telah dilaksanakan di 32 provinsi di Indonesia yang menyentuh guru pengampu berbagai mata pelajaran (IPS, IPA, Bahasa Inggris, Bahasa Indonesia, dan lainlainnya). Penerapan program di tahun 2016 relatif kecil dibanding jumlah guru yang ada, yakni baru mencakup sekitar 420 ribu orang, sekitar 85 ribu orang diantaranya adalah guru di jenjang Sekolah Menengah Pertama.

Dari jawaban guru yang diteliti diperoleh, bahwa proses pelatihan melalui program Guru Pembelajar dapat meningkatkan kompetensi mereka, meski tidak terlalu signifikan. Namun data hasil pre-test (menggunakan data UKG 2015) dan evaluasi (post-test) di tahun 2016 oleh Ditjen GTK sendiri mengindikasikan sebaliknya, yakni adanya kondisi kompetensi guru yang cenderung menurun meski 
telah menjalani pelatihan GP (lihat Tabel 2).

Tabel 2

Hasil Pre-test dan Post-test Penerapan Program Guru Pembelajar

\begin{tabular}{|c|c|c|c|c|c|}
\hline \multirow[b]{2}{*}{ Provinsi } & \multicolumn{4}{|c|}{ Program Guru Pembelajar } & \multirow{2}{*}{$\begin{array}{l}\text { Perubahan } \\
\text { kompetens }\end{array}$} \\
\hline & $\begin{array}{c}\text { Pre-test } \\
\text { UKG } 2015\end{array}$ & Jumlah & $\begin{array}{c}\text { UKG } 2015 \\
\text { (pre-test) }\end{array}$ & Post-test & \\
\hline Papua & 49,38 & 400 & 58,11 & 50,39 & $-7,72$ \\
\hline $\begin{array}{l}\text { Sulawesi } \\
\text { Barat }\end{array}$ & 49,96 & 1.406 & 50,48 & 44,74 & $-5,74$ \\
\hline $\begin{array}{l}\text { DI } \\
\text { Yogyakarta }\end{array}$ & 64,38 & 5.866 & 64,40 & 59,62 & $-5,01$ \\
\hline $\begin{array}{l}\text { Kalimantan } \\
\text { Barat }\end{array}$ & 53,39 & 6.475 & 50,40 & 45,43 & $-4,97$ \\
\hline $\begin{array}{l}\text { Jawa } \\
\text { Tengah }\end{array}$ & 61,77 & 51.177 & 57,98 & 53,71 & $-4,25$ \\
\hline $\begin{array}{l}\text { Papua } \\
\text { Barat }\end{array}$ & 49,26 & 295 & 48,90 & 44,73 & $-4,17$ \\
\hline DKI Jakarta & 59,18 & 12.493 & 60,11 & 55,96 & $-4,14$ \\
\hline Jawa Timur & 58,2 & 66.427 & 60,69 & 56,69 & $-3,98$ \\
\hline Banten & 54,46 & 11.562 & 55,97 & 52,28 & $-3,70$ \\
\hline $\begin{array}{l}\text { Kalimantan } \\
\text { Utara }\end{array}$ & 54,78 & 1.350 & 49,18 & 45,55 & $-3,63$ \\
\hline $\begin{array}{l}\text { Kalimantan } \\
\text { Tengah }\end{array}$ & 50,89 & 2.428 & 51,24 & 47,83 & $-3,41$ \\
\hline $\begin{array}{l}\text { Maluku } \\
\text { Utara }\end{array}$ & 42,59 & 1.051 & 40,65 & 37,40 & $-3,24$ \\
\hline Maluku & 46,17 & 1.560 & 46,93 & 43,76 & $-3,18$ \\
\hline Lampung & 51,67 & 23.723 & 53,28 & 50,63 & $-2,65$ \\
\hline $\begin{array}{l}\text { Kepulauan } \\
\text { Riau }\end{array}$ & 56,12 & 1.405 & 58,14 & 55,77 & $-2,37$ \\
\hline $\begin{array}{l}\text { Nusa } \\
\text { Tenggara } \\
\text { Barat }\end{array}$ & 49,31 & 6.689 & 52,05 & 49,78 & $-2,27$ \\
\hline $\begin{array}{l}\text { Kalimantan } \\
\text { Timur }\end{array}$ & 53,79 & 11.272 & 50,46 & 48,33 & $-2,13$ \\
\hline Bali & 57,62 & 10.801 & 56,74 & 54,78 & $-1,96$ \\
\hline $\begin{array}{l}\text { Sulawesi } \\
\text { Utara }\end{array}$ & 49,03 & 1.005 & 49,11 & 47,16 & $-1,95$ \\
\hline $\begin{array}{l}\text { Sumatera } \\
\text { Utara }\end{array}$ & 50,65 & 19.724 & 50,82 & 48,97 & $-1,84$ \\
\hline $\begin{array}{l}\text { Sulawesi } \\
\text { Tengah }\end{array}$ & 48,42 & 2.645 & 51,69 & 49,88 & $-1,79$ \\
\hline $\begin{array}{l}\text { Nusa } \\
\text { Tenggara } \\
\text { Timur }\end{array}$ & 47,46 & 17.528 & 50,34 & 48,68 & $-1,66$ \\
\hline Riau & 52,85 & 6.556 & 51,22 & 49,61 & $-1,62$ \\
\hline $\begin{array}{l}\text { Sumatera } \\
\text { Selatan }\end{array}$ & 49,89 & 15.478 & 51,00 & 49,63 & $-1,36$ \\
\hline Bengkulu & 51,58 & 2.584 & 51,96 & 50,84 & $-1,10$ \\
\hline $\begin{array}{l}\text { Kalimantan } \\
\text { Selatan }\end{array}$ & 56,64 & 4.862 & 51,02 & 49,99 & $-1,03$ \\
\hline $\begin{array}{l}\text { Sulawesi } \\
\text { Selatan }\end{array}$ & 50,81 & 22.682 & 53,10 & 52,23 & $-0,87$ \\
\hline $\begin{array}{l}\text { Sumatera } \\
\text { Barat }\end{array}$ & 55,78 & 12.177 & 53,68 & 53,11 & $-0,57$ \\
\hline Gorontalo & 49,19 & 5.191 & 49,56 & 49,21 & $-0,35$ \\
\hline Aceh & 44,93 & 9.683 & 49,05 & 48,73 & $-0,33$ \\
\hline Jawa Barat & 56,69 & 85.387 & 57,37 & 57,11 & $-0,23$ \\
\hline $\begin{array}{l}\text { Bangka } \\
\text { Belitung }\end{array}$ & 58,79 & 455 & 49,19 & 49,80 & 0,62 \\
\hline Jambi & 50,86 & 2.984 & 50,03 & 52,48 & 2,45 \\
\hline $\begin{array}{l}\text { Sulawesi } \\
\text { Tenggara }\end{array}$ & 49,76 & 1.868 & 48,21 & 54,76 & 6,55 \\
\hline Total & 54,51 & 427.189 & 55,53 & 53,30 & $-2,23$ \\
\hline
\end{tabular}

*diolah dari data Ditjen GTK, tahun 2017

Hasil ini mengherankan, mengapa setelah memperoleh pelatihan justru kompetensi guru menjadi menurun? Apa kekurangan atau kelemahan yang dihadapi dalam pelatihan tersebut? Jawaban pertanyaan ini memang masih memerlukan pengkajian yang mendalam dan terarah. Memang dari data yang ada, diperlihatkan bahwa penerimaan type moda daring dan kombinasi mengindikasikan hasil yang menurun, sebaliknya dengan moda tatap muka menunjukkan peningkatannya (lihat Tabel 3). Padahal jumlah modul yang harus dipelajari selama kurang lebih dua minggu dalam moda daring dan kombinasi relatif sedikit (antara 2-4 atau 3-5 modul), sebaliknya dengan moda tatap muka yang mencapai 8-10 modul (Ditjen GTK, 2016). Berbagai pendapat dilontarkan guru mengenai penyebab situasi ini, seperti (1) modul yang diberikan tidak sesuai, instrumen tes tidak sesuai dengan modul yang dipelajari; (2) instruktur sulit dihubungi; (3) tidak tersedia media komputer; (4) sinyal internet yang lemah, dan sebagainya.

Tabel 3

Hasil Pre-test dan Post-test Guru SMP Peserta Pelatihan GP

\begin{tabular}{clccc}
\hline No & $\begin{array}{c}\text { Moda } \\
\text { pembelajaran }\end{array}$ & $\begin{array}{c}\text { Pre-test } \\
(\mathrm{UKG} \\
\text { 2015) }\end{array}$ & $\begin{array}{c}\text { Post-test } \\
(2016)\end{array}$ & $\begin{array}{c}\text { Jumlah } \\
\text { peserta }\end{array}$ \\
\hline 1 & $\begin{array}{l}\text { D a r i n g } \\
\text { kombinasi }\end{array}$ & 56,97 & 56,61 & 31.544 \\
2 & $\begin{array}{l}\text { Daring murni } \\
\text { type 1 }\end{array}$ & 69,11 & 63,95 & 9.620 \\
3 & $\begin{array}{l}\text { Daring murni } \\
\text { type 2 }\end{array}$ & 64,65 & 61,32 & 16.272 \\
$4 \quad$ Tatap muka & 48,75 & 52,99 & 27.954 \\
\hline Total rata-rata & 57,11 & 57,15 & 85.390 \\
\hline
\end{tabular}

*diolah dari data Ditjen GTK, tahun 2017

Melihat hasil program pelatihan yang dijalankan oleh Ditjen GTK terhadap guru, diperlukan upaya lain yang dapat memotivasi dan mendorong guru untuk terus-menerus meningkatkan kompetensi, kemampuan, dan profesionalisme kerja, sehingga dapat berdampak positif terhadap peningkatan kualitas pendidikan keluarannya. Pemenuhan jam mengajar dapat menjadi entry point untuk mencapai tujuan tersebut, tetapi bukanlah pemenuhan yang melulu berorientasi dari sisi kuantitas melainkan penekanan terhadap kualitas. Pemenuhan jam mengajar bukan semata-mata ditinjau dari jumlah JTM guru, melainkan terkait dengan upaya guru dalam mewujudkan aspek-aspek pengembangan profesionalisme kerja, mewujudkan kinerja, pencapaian hasil belajar, keterlibatan dalam pendidikan karakter siswa, melakukan penelitian tindakan kelas untuk memecahkan permasalahan 
pembelajaran, menjalankan pembelajaran tatap muka, dan melaksanakan tugas tambahan lain.

Pemikiran yang disebut terakhir itulah yang akan dibahas lebih lanjut di bawah ini, sebagai upaya agar guru dapat memenuhi kewajiban jam mengajar. Pemenuhan itu dikaitkan dengan diri guru sendiri dalam menjalankan tugas utama mengajar, bukan sesuatu hal yang harus dicari di luar sekolah atau tempat lainnya. Selayaknya pemenuhan jam mengajar guru berhimpit dengan peningkatan kemampuan dan profesionalisme kerja, bahkan perolehan Tunjangan Profesi Guru (TPG). Perbedaan yang ada berhubungan dengan kemampuan merencanakan, melaksanakan, dan mengevaluasi jam kerja yang dijalankan, yang dilandasi oleh motivasi, komitmen, dan upaya yang diwujudkan. Dengan demikian, pencapaian jam mengajar antara satu guru dengan guru lain dapat dilihat dari motivasi dan komitmen tersebut, dan bahkan menunjukkan apakah ia telah melaksanakan tugas secara baik dan mencapai hasil belajar siswa yang baik atau sebaliknya.

Dalam tulisan ini dikemukakan sejumlah aspek yang memiliki sejumlah indikator untuk menentukan perilaku pembelajaran yang akan dilaksanakan selama satu tahun. Aspek-aspek tersebut terkait dengan (a) Pengembangan Keprofesian Berkelanjutan (PKB); (b) kinerja; (c) hasil belajar; (d) penguatan pendidikan karakter; (e) Penelitian Tindakan Kelas (PTK); (f) tugas tambahan; dan (g) jam mengajar riil. Pengisian masingmasing aspek dilakukan melalui pendekatan Gaya Likert, melalui (a) pemberian skor tertentu terhadap alternatif pilihan jawaban yang dipilih; (b) menjumlah skor jawaban setiap aspek; dan (c) mengekuivalensikan untuk menentukan bobot nominal masing-masing aspek. Jumlah keseluruhan bobot nominal ekuivalensi menentukan jumlah jam mengajar yang dimiliki oleh guru. Terutama penentuan skor jawaban yang dipilih, didasarkan atas kriteria (1) pemberian angka 1 apabila guru tidak menginginkan adanya peningkatan; (2) pemberian angka 2 apabila guru menginginkan adanya sedikit peningkatan; (3) pemberian angka 3 apabila guru menginginkan adanya cukup/sedang meningkat; dan (4) pemberian angka 4 apabila guru menginginkan adanya sangat meningkat.

Mekanisme kerja setiap aspek dilakukan awal tahun oleh guru dengan merancang perencanaan kerja dan menentukan skor yang ingin dicapai dalam satu satu tahun ajaran, menjumlahkan skor jawaban setiap aspek, dan menetapkan bobot ekuivalensi. Aspek pertama dalam pemenuhan jam mengajar guru terkait dengan Pengembangan Keprofesionalan Berkelanjutan (PKB) atau Continuing Professional Development (CPD)
(Leithwood dkk, 1998; Agung, 2013; Agung, 2018). Dalam PKB ini terdapat 12 indikator penilaian, yakni (1) upaya guru dalam melaksanakan pengayaan materi, teori, konsep dan pengembangan pola pikir terhadap keilmuan dari mata pelajaran yang diampu; (2) upaya meningkatkan pendidikan formal; (3) upaya mengikuti pelatihan pengembangan profesi; (4) upaya mencari bimbingan/bantuan penguasaan materi dan metode pembelajaran; (5) upaya meningkatkan kreativitas untuk pemanfaatan metode pembelajaran yang variatif; (6) keaktifan dalam organisasi profesi; (7) upaya menguasai pemanfaatan Teknologi Informasi dan Komunikasi (TIK) untuk pembelajaran; (8) upaya meningkatkan kemampuan dan pemanfaatan teknologi digital, peningkatan kemampuan dan pemanfaatan pendekatan problem based learning \& project based learning (Barge, 2010; De Graaf, 2003; Hmelo, 2004; Lambros, 2004; Rhem, 1998); (9) upaya peningkatan kemampuan menggunakan pendekatan saintifik; (10) upaya pemanfaatan hasil evaluasi untuk penguatan dan reflektif; (11) upaya meningkatkan kemampuan komunikasi pembelajaran; dan (12) upaya memanfaatkan potensi lingkungan dalam pengembangan diri dan pembelajaran.

Kategori Penilaian dari aspek Pengembangan Keprofesian Berkelanjutan (PKB) yang diusulkan dengan jumlah penilaian minimal 12 dan maksimal 48 dengan ekuivalensi pembobotan antara 2-8 terlihat pada Tabel 4.

Tabel 4

Kategori Penilaian dari Aspek Pengembangan Keprofesian Berkelanjutan (PKB)

\begin{tabular}{ll}
\hline \multicolumn{1}{c}{ Kriteria penilaian } & Ekuivalensi bobot penilaian \\
\hline $\begin{array}{l}\text { Penjumlahan skor kurang } \\
\text { dari 12 }\end{array}$ & $=2 /$ Tidak ada peningkatan $(\mathrm{TM})$ \\
Penjumlahan skor $13-24$ & $=4 /$ Kurang Meningkat $(\mathrm{KM})$ \\
Penjumlahan skor 25 -36 & $=6 /$ Cukup Meningkat $(\mathrm{CM})$ \\
Penjumlahan skor 37 -48 & $=8 /$ Sangat Meningkat $(\mathrm{SM})$ \\
\hline
\end{tabular}

Aspek kedua, pemenuhan jam mengajar guru juga dikaitkan dengan kinerja yang diwujudkan dalam menjalankan tugas/pekerjaan utama. Kinerja merupakan tampilan kerja seorang/sekelompok guru dalam melaksanakan tugas/pekerjaannya (Robins \& Judge, 1997; Davis, 2004). Dalam tulisan ini, aspek kinerja terdiri dari lima indikator, yakni (1) kemandirian; (2) kuantitas kerja; (3) kualitas kerja; (4) pengelolaan waktu; dan (5) pengelolaan sumber daya pembelajaran. Dalam indikator kemandirian meliputi sub-sub indikator (a) kemandirian dalam menyusun perencanaan dan pelaksanaan pembelajaran (merancang dan mengembangkan 
materi dan tujuan pembelajaran, pengelolaan kelas, proses pembelajaran, pemanfaatan fasilitas belajar, pemanfaatan metode pembelajaran, komunikasi pembelajaran, dan pengembangan instrumen evaluasi; (b) kemandirian dalam merancang, mengembangkan, dan memanfaatkan TIK dalam pembelajaran; (c) kemandirian dalam merancang dan melaksanakan penguatan, analisis, dan refleksi pembelajaran; (d) kemandirian dalam merencanakan dan melaksanakan PTK; dan (e) kemandirian dalam menganalisis gejala/permasalahan pembelajaran. Dalam indikator kuantitas kerja meliputi sub-sub indikator (a) pencapaian hasil kerja, (b) jumlah jam bimbingan belajar, (c) penambahan jam belajar, (d) partisipasi KKG/MGMP, dan pemenuhan tugas administratif. Dalam indikator kualitas kerja meliputi sub-sub indikator (a) pencapaian tujuan dan hasil kerja, (b) kualitas konsistensi perencanaan dan pelaksanaan pembelajaan, (c) kualitas hasil belajar peserta didik/ siswa, (d) kualitas hubungan kerja rekan sejawat, dan (e) kualitas kemampuan analisis dan pemecahan masalah pembelajaran.

Dalam indikator pengelolaan waktu meliputi sub-sub indikator (a) pengelolaan waktu pembelajaran di kelas, (b) disiplin kehadiran di sekolah, (c) konsistensi pelaksanaan waktu pembelajaran tambahan, (d) pengelolaan waktu pemberian tugas pembelajaran, dan (e) disiplin kehadiran di KKG/MGMP.

Dalam indikator pengelolaan sumber daya meliputi sub-sub indikator (a) pemanfaatan laboratorium sekolah; (b) pemanfaatan perpustakaan sekolah; (c) pemanfaatan sumber media surat kabar, majalah, tv, internet, jurnal, dan-lain-lain; (e) pemanfaatan narasumber/pakar; dan (f) pemanfaatan TIK dan teknologi digital lain dalam pembelajaran.

Kategori penilaian dari aspek kinerja yang diusulkan dengan jumlah penilaian minimal 25 dan maksimal 100 dengan ekuivalensi bobot penilaian antara 2-8 terlihat pada Tabel 5 .

Tabel 5

Kategori Penilaian dari Aspek Kinerja

\begin{tabular}{|c|c|}
\hline Kriteria penilaian & Ekuivalensi bobot penilaian \\
\hline $\begin{array}{l}\text { Penjumlahan skor kurang } \\
\text { dari } 25\end{array}$ & $=2 /$ \\
\hline Penjumlahan skor $16-50$ & $=4 /$ Kurang Meningkat $(\mathrm{KM})$ \\
\hline Penjumlahan skor 51- 75 & $=6 /$ Cukup Meningkat $(\mathrm{CM})$ \\
\hline Penjumlahan skor 76 - 100 & $=8 /$ Sangat Meningkat $(\mathrm{SM})$ \\
\hline
\end{tabular}

Aspek ketiga, pemenuhan jam mengajar guru dikaitkan pula dengan pencapaian hasil belajar siswa. Apresiasi harus diberikan terhadap pencapaian hasil belajar siswa, apabila hasil belajar tinggi maka perlu diberikan apresiasi yang tinggi terhadap guru, sebaliknya jika rendah apresiasi yang diberikan pun rendah. Namun penilaian tersebut tidak berhenti dan dibiarkan saja, melainkan harus ada upaya yang dapat "memaksa" peningkatan kemampuan guru dan pencapaian hasil belajar siswa. Aspek pertama dan kedua di atas diharapkan dapat menjadi instrumen yang mampu menstimulir dan mendorong guru untuk meningkatkan kemampuan diri dan pencapaian hasil belajar siswa.

Kategori penilaian dari aspek hasil belajar yang diusulkan dengan ekuivalensi bobot penilaian antara 2 - 6 terlihat pada Tabel 6.

Tabel 6

Kategori Penilaian dari Aspek Hasil Belajar

\begin{tabular}{lc}
\hline \multicolumn{1}{c}{ Kriteria penilaian } & Ekuivalensi bobot penilaian \\
\hline $\begin{array}{l}\text { Jumlah angka rata-rata US } \\
\text { dan UN }<5\end{array}$ & $=2$ (rendah/ kurang memuaskan) \\
Jumlah angka rata-rata US & $=4$ (cukup/memuaskan) \\
dan UN $6-7$ & \\
Jumlah angka rata-rata $>8$ & $=6$ (sangat baik/sangat memuaskan) \\
\hline
\end{tabular}

Aspek keempat, pemenuhan jam mengajar guru dikaitkan dengan keterlibatan aktif dalam Penguatan Pendidikan Karakter (PPK), baik melalui pengintegrasian nilai karakter ke dalam intrakurikuler maupun kegiatan ekstra dan ko-kurikuler. Hal ini menunjukkan, bahwa guru bukan hanya menjadi penyampai pesan nilai-nilai keilmuan dan nilai-nilai karakter melalui intrakurikuler, tetapi juga dalam pelaksanaan ekstra-kokurikuler untuk membentuk kepribadian dan karakter siswa. Terutama dalam kegiatan ekstra - nonkurikuler, guru dapat berperan sebagai penyusun materi pendidikan karakter, anggota pelaksana kegiatan, instruktur, dan lain-lainnya. Subsub indikator dalam pendidikan karakter meliputi (a) integrasi PPK dalam intrakurikuler, (b) partisipasi dalam penyusunan materi dan kegiatan PPK, (c) keaktifan sebagai anggota dalam kegiatan PPK, (d) keaktifan sebagai instruktur PPK, (e) keikutsertaan dalam pengelolaan PPK, dan (f) pemanfaatan kearifan lokal dalam pembelajaran.

Kategori pemberian bobot ekuivalensi dari aspek Penguatan Pendidikan Karakter (PPK) antara 1 -6, dengan penilaian sesuai dengan keterlibatan guru dalam kegiatan penguatan pendidikan karakter. Misal, jika guru hanya mengintegrasikan upaya penguatan pendidikan karakter ke dalam intrakurikuler hanya mendapat ekuivalensi bobot penilaian 1; jika dua kegiatan mendapat ekuivalensi bobot penilaian 2; dan seterusnya.

Aspek kelima, pemenuhan jam mengajar guru 
terkait pula dengan keaktifan melakukan Penelitian Tindakan Kelas (PTK), khususnya dalam upaya memecahkan permasalahan mengenai pembelajaran. PTK pada dasarnya dapat menjadi wahana bagi guru untuk memperoleh dan menggambarkan suatu gejala terkait pembelajaran melalui kaidah, metode, dan teknik ilmiah yang sistematis dan terarah, kemudian memahami dan mengambil konklusi pemecahannya (Agung, 2014). Tindakan PTK guru menjadi penting, selaras dengan tuntutan menjalankan pendekatan problem based learning \& project based learning guna mengantisipasi, merespon, dan adaptif terhadap perkembangan dan perubahan lingkungan strategis jaman saat ini. Dari aspek ini hanya terdiri dari dua sub indikator, yakni kemampuan menghasilkan karya PTK tidak terpublikasi dan kemampuan menghasilkan karya PTK terpublikasi. Bobot penilaian antara $0-4$, yakni (a) pemberian bobot ekuivalensi 0 (nol) jika guru sama sekali tidak pernah melakukan PTK; (b) pemberian bobot ekuivalensi 2 (dua) jika guru melakukan PTK tidak terpublikasi; dan (c) pemberian bobot ekuivalensi 4 (empat) jika guru melakukan PTK terpublikasi.

Aspek keenam, pemenuhan jam mengajar terkait dengan jenis tugas tambahan yang diperoleh guru dari sekolah tempat bekerja maupun di luar sekolah, meliputi indikator (a) menjadi wali kelas; (b) mengajar mata pelajaran yang sama/ mata pelajaran lain; (c) menjadi tutor Paket A, B, C program kesetaraan; (d) menjadi guru bina sekolah terbuka; (e) menjadi guru pamong sekolah terbuka; (f) melaksanakan pembelajaran perbaikan (remedial teaching); (g) mengelola kegiatan keagamaan; (h) menjadi guru inti/instruktur KKG/MGMP; (i) aktif dalam pengelolaan PNPM; dan (j) aktif dalam pembinaan pendidikan masyarakat. Bobot penilaian ekuivalensi diusulkan berkisar antara $0-6$, dengan kriteria terlihat pada Tabel 7.

Tabel 7

Kategori Penilaian Terkait Jenis Tugas Tambahan

\begin{tabular}{lc}
\hline \multicolumn{1}{c}{ Kriteria penilaian } & Ekuvalensi bobot penilaian \\
\hline $\begin{array}{l}\text { Jika guru tidak melaksanakan } \\
\text { tugas tambahan memperoleh } \\
\text { bobot ekuivalensi }\end{array}$ & $=0$ \\
Jika guru melaksanakan $1-2$ & $=2$ \\
tugas tambahan mendapat & \\
bobot ekuivalansi & $=4$ \\
Jika guru melaksanakan $3-5$ & \\
tugas tambahan mendapat \\
bobot ekuivalensi \\
$\begin{array}{l}\text { Jika guru melaksanakan } \\
\text { lebih dari } 6 \text { tugas tambahan } \\
\text { mendapat bobot ekuivalensi }\end{array}$
\end{tabular}

Akhirnya, apabila pada aspek kesatu sampai dengan keenam, perhitungan bobot ekuivalensi didasarkan kategori penilaian tertentu, tetapi pada aspek ketujuh ditetapkan sesuai JTM riil. Misal seorang guru mendapat jam mengajar sebanyak 8 (delapan) jam per minggu di sekolah tempat mengajar, maka akan ditulis memperoleh bobot ekuivalensi 8, mendapat 15 jam mengajar per minggu akan ditulis memperoleh bobot ekuivalensi 15, dan seterusnya.

Dari bobot ekuivalensi ketujuh unsur/aspek di atas, diperoleh rumus penilaian sebagai berikut:

$$
\text { TEJMG }=\text { Subtotal }(\mathrm{A}+\mathrm{B}+\mathrm{C}+\mathrm{D}+\mathrm{E}+\mathrm{F})+(\mathrm{G})
$$

*TEJMG = Total Ekuivalensi Jam Mengajar Guru

Keenam unsur/aspek penilaian jam mengajar guru disusun dalam bentuk matriks yang akan dibuat dua kali oleh guru, yaitu di awal tahun ajaran dan pada akhir tahun ajaran. Awal tahun ajaran guru akan merancang perencanaan jam mengajar, sebagai pranata pengendali atau pedoman yang mengarahkan perilaku pelaksanaan kerja selama satu tahun ke depan dengan mendapat persetujuan kepala sekolah dan pengawas. Pada akhir tahun ajaran, guru melakukan sendiri penilaian terhadap rancangan perencanaan kerja jam mengajar yang dibuatnya (self assessment/ self evaluation) secara objektif dengan disertai buktibukti. Hasil penilaian diperiksa kebenarannya untuk mendapat persetujuan dan pengesahan oleh kepala sekolah dan pengawas. Self assessment oleh guru, bukan hanya dapat menjadi refleksi bagi guru, tetapi juga pihak sekolah dan lainnya untuk memberikan perlakuan yang dibutuhkan guna meningkatkan kemampuan dan keterampilan pembelajaran guru. Pada dasarnya, apa yang disusun oleh guru dapat dikatakan sebagai evaluasi kinerja selama satu tahun ajaran, sekaligus memotivasi dan mendorong guru untuk lebih meningkatkan kemampuan menjalankan tugas (Mangkunegara, 2010).

Berikut ini dikemukakan contoh penerapan perencanaan dan pelaksanaan jam kerja guru,

"Agus Santosa usia 45 tahun guru mata pelajaran Matematika telah mengajar di SMP Negeri Jombang selama 20 tahun. Namun dalam melaksanakan tugas mengajar dirinya hanya mendapat 10 jam mengajar tatap muka untuk siswa kelas III. Ia tidak dapat memenuhi beban kewajiban mengajar minimal 24 jam/minggu, dan kesulitan untuk memperoleh tunjangan profesi guru. Padahal dirinya tergolong sebagai guru yang aktif, disenangi siswa, kreatif, dan mampu menunjukkan pencapaian hasil belajar siswanya yang baik". 


\section{PEMBAHASAN}

Jika menyimak perencanaan jam mengajar, guru Agus Santosa yang mencatat jumlah 36 JMG, pada penilaian pelaksanaan selama satu tahun ajaran, menunjukkan bahwa guru yang bersangkutan berhasil mencapat jumlah 38 JMG. Hal ini sekaligus menunjukkan, bahwa guru Agus Santoso mampu secara konsisten memotivasi dan mendorong perilaku kerja searah dengan perencanaan yang dibuat, dan bahkan mencapai hasil akhir melebihi target yang dicanangkan. Implisit, matriks perencanaan dan pelaksanaan jam mengajar cenderung digunakan sebagai instrumen oleh guru dalam mengendalikan perilaku kerja, serta langsung maupun tidak langsung meningkatkan kompetensi, profesionalisme, dan kinerja pembelajaran. Pengisian matriks menjadikannya sebagai alat kontrol atau pranata pengendali dalam menjalankan tugas utama mengajarnya, dan tahap demi tahap akan mengarahkan pada perubahan sikap dan perilaku kerja yang terus membaik.

Unsur, indikator, subindikator, parameter penilaian, serta bobot ekuivalensi, merupakan pemikiran yang dapat diterapkan kepada guru. Kelima komponen merupakan instrumen bagi guru untuk memotivasi diri (self motivation), mendorong, dan komitmen menjalankan tugas. Ada dua fungsi dari pengisian instrumen, pertama, mengetahui apakah guru merencanakan pelaksanaan tugas yang dinamis, dalam arti berupaya meningkatkan kualitas pelaksanaan tugas pembelajaran atau sebaliknya; dan kedua, seberapa besar guru merencanakan untuk mencapai jam mengajar (JMG). Pihak kepala sekolah dan pengawas pun dapat mengetahui secara langsung kecenderungan guru dalam menjalankan tugas pembelajaran selama satu tahun ajaran, baik terkait dengan upaya pengembangan keprofesian, kinerja, hasil belajar, keterlibatan dalam pendidikan karakter, dan keaktifan melaksanakan PTK, kemudian memberikan bimbingan dan bantuan yang diperlukan. Pada akhir tahun ajaran, dapat dilihat pencapaian pelaksanaan tugas pembelajaran oleh guru, apakah mengalami peningkatan seperti yang direncanakan atau tidak.

Jika terjadi peningkatan, maka guru yang bersangkutan dapat menggunakan hasil di akhir tahun ajaran sebagai kondisi awal untuk merencanakan pelaksanaan kerja di tahun berikutnya. Tahap demi tahap, guru akan mencapai peningkatan kompetensi, profesionalisme dan kinerja, serta meningkatkan hasil belajar peserta didik/siswanya. Sebaliknya, apabila guru tidak mengalami perubahan pelaksanaan tugas, dan bahkan tidak mencapai hasil sesuai dengan perencanaan yang dibuat, hasil di akhir tahun ajaran dapat memberikan gambaran kondisi kemampuan dan kompetensi yang dimiliki oleh guru yang bersangkutan. Dengan bimbingan dan bantuan pihak yang berkepentingan (kepala sekolah, pengawas, dan narasumber/pakar), guru yang bersangkutan pun dapat menyusun perencanaan jam mengajar selanjutnya. Pemantauan, bimbingan, dan bantuan perlu dilakukan oleh kepala sekolah, pengawas, dan petugas yang ditunjuk, agar pelaksanaan pembelajaran tetap terkendali dan terarah baik.

Satu hal yang patut digarisbawahi, instrumentasi perencanaan dan pelaksanaan jam mengajar akan membawa guru untuk menjadi pembelajar dengan terus-menerus mengembangkan diri. Begitu juga dengan pihak-pihak yang berkepentingan di dalamnya, kepala sekolah dan pengawas misalnya, dituntut untuk meningkatkan kemampuan dan keterampilannya dalam memberikan bimbingan dan bantuan kepada guru. Tenaga nonkependidikan di sekolah pun akan berupaya menyiapkan data dan informasi yang memadai untuk mendukung tugas pembelajaran guru. Siswa akan lebih aktif melaksanakan pembelajaran, dan bahkan orang tua akan turut berpartisipasi aktif mendukung aktivitas di sekolah. Segenap hal ini akan bermuara pada penciptaan dinamisasi iklim sekolah sebagai organisasi pembelajar (learning organization) yang tahap demi tahap melakukan perubahan dan perbaikan.

Seperti yang dikemukakan Fiol \& Marjorie (1985), organisasi pembelajar sebagai proses perbaikan tindakan melalui peningkatan pemahaman dan pengetahuan. Suatu organisasi pembelajar merupakan kemampuan organisasi untuk tanggap dan mampu menjawab berbagai kondisi lingkungan internal dan eksternalnya yang mempengaruhi keberhasilannya. Senge (1990) mengartikan organisasi pembelajar sebagai "... organizations where people continually expand their capacity to create the results they truly desire, where new and expansive patterns of thinking are nurtured, where collective aspiration is set free, and where people are continually learning to see the whole together". Pedler (1998) mendefinisikan sebagai "... is a vision of what might be possible. It is not brought about simply by training individuals; it can only happen as a result of learning at the whole organization level. A learning company is an organization that facilitates the learning of all its members and continuously transforms itself". Watkin \& Marsic (1993) mengartikan sebagai “... characterized by total employee involvement in a process of 
collaboratively conducted, collectively accountable change directed towards shared values or principles". Simatupang (1995) memberi pengertian sebagai organisasi yang sangat adaptif dan responsif terhadap lingkungan eksternal dan internalnya, sedangkan Marquardt (1996) mengatakan sebagai suatu organisasi yang berkemampuan belajar secara kolektif dan terusmenerus untuk mengubah dirinya menjadi lebih baik, mengelola, dan menggunakan pengetahuan untuk kesuksesan organisasinya. Dalt (2010) mengemukakan ada sejumlah aspek yang perlu diperhatikan dalam pengembangan organisasi pembelajar, yakni (a) kepemimpinan; (b) struktur kerja berbasis tim; (c) partisipatif staf; (d) keterbukaan informasi; dan (e) pengembangan budaya organisasi yang kondusif.

\section{Jam Mengajar Guru dan Tunjangan Profesi Guru}

Pemikiran di atas dikemukakan sebagai terobosan bagi guru memenuhi beban kewajiban mengajar minimal 24 jam/minggu dan maksimal 40 jam/minggu. Alternatif yang diajukan berperan ganda, di satu sisi, guru tidak perlu mencari penambahan jam mengajar di luar sekolah tempat menjalankan tugas/ pekerjaan utama, di sisi lain akan memotivasi dan mendorong guru untuk senantiasa meningkatkan kompetensi dan profesionalisme kerja.

Perhitungan Jam Mengajar Guru (JMG) sewajarnya digunakan pula sebagai acuan untuk menerapkan pemberian Tunjangan Profesi Guru (TPG). TPG adalah tunjangan penghasilan yang diberikan kepada guru setelah memenuhi persyaratanpersyaratan yang telah ditetapkan. Tunjangan profesi sebesar satu bulan gaji pokok yang diterima bagi guru pemerintah (PNS) dan guru tetap bukan PNS sebesar Rp. 1.500.000,- (satu juta lima ratus ribu rupiah) per bulan setelah memenuhi persyaratan yang sesuai dengan ketentuan perundang-undangan yang berlaku, dan dikenakan pajak penghasilan sesuai dengan ketentuan perpajakan (Ditjen Anggaran, 2015. https:/ / www.kanalinfo.web.id/2016/03/tunjangan-profesiguru.html).

Satu kritik kerap kali diajukan terhadap pemberian TPG ini, karena dianggap jauh dari rasa keadilan. Guru yang baik dan kurang baik tetapi memiliki pengalaman mengajar jenjang kepangkatan sama, cenderung akan memperoleh TPG yang sama pula. Situasi seperti ini kurang memotivasi guru untuk meningkatkan kemampuan diri dan hasil belajar peserta didiknya, dan bahkan akan mempengaruhi guru-guru lain untuk berperilaku yang sama. Guru yang baik akan menjadi malas berprestasi, disebabkan oleh tidak adanya perbedaan perlakuan dalam perolehan TPG dengan guru yang kurang berprestasi.

Atas dasar tersebut disarankan, selaras dengan penerapan alternatif pemikiran di atas perlu dipertimbangkan hasil penilaian akhir dikaitkan dengan perolehan TPG. Hasil penilaian pemenuhan jam mengajar guru perlu dikaitkan dengan perolehan TPG guru, melalui usulan sebagai berikut.

$\begin{array}{ll}\text { Pencapaian < 24 JMG } & =70 \% \mathrm{TPG} \\ \text { Pencapaian antara 25 - 32 JMG } & =80 \% \mathrm{TPG} \\ \text { Pencapaian > 33 JMG } & =100 \% \mathrm{TPG}\end{array}$

TPG diberikan pada tahap perencanaan di awal tahun ajaran TPG sebesar 70\%. Selanjutnya perolehan TPG akan diberikan setelah penilaian JMG di akhir tahun ajaran, disesuaikan dengan hasil penilaian dan perolehan TPG menurut ketentuan yang ada. Apabila pada akhir tahun ajaran, guru hanya mencapai perhitungan dan penilaian kurang 24 JMG, maka hanya memperoleh sebesar 70\% TPG, tetapi jika mencapai lebih dari 24 JMG akan memperoleh sebesar $80 \%$ atau $100 \%$ TPG.

Bagi guru yang tidak memperoleh TPG penuh, tidak akan kehilangan haknya terhadap sisa dana TPG yang ada. Namun, sisa dana tersebut diarahkan oleh pihak sekolah dan pengawas agar guru dapat menggunakannya untuk peningkatan kemampuan diri, seperti (a) memanggil pakar/narasumber untuk memberikan pembimbingan pembelajaran; (b) memenuhi kelengkapan fasilitas pembelajaran yang dibutuhkan guru; serta (c) penunjang kegiatan guru mengikuti pertemuan di KKG/MGMP, dan sebagainya.

\section{PENUTUP}

\section{Kesimpulan}

Pemenuhan jam mengajar guru sesuai dengan ketentuan minimal 24 jam/minggu dan maksimal 40 jam/minggu seharusnya tidak ditinjau hanya dari segi kuantitas, tetapi juga kualitas. Untuk apa guru memenuhi persyaratan yang ditentukan dalam peraturan dengan mencari ke sekolah lain atau dalam bentuk tugas tambahan, apabila itu hanya sekedar menyebarkan hasil belajar yang bermutu rendah. Dalam tulisan ini dikemukakan alternatif pemenuhan jam mengajar guru, selain tidak perlu mencari di luar sekolah juga dapat menjadi pendorong bagi peningkatan dan pengembangan kemampuan kompetensi, dan profesionalisme kerja guru.

\section{Saran}

Alternatif pemikiran mengenai jam mengajar guru yang diajukan di sini, layak untuk dipertimbangkan dan diterapkan kepada guru-guru. Pemikiran berfungsi ganda, di satu sisi, merupakan 
upaya meningkatkan kemampuan guru, di sisi lain dapat menjadi entry point bagi peningkatan mutu pendidikan. Penerapan alternatif pemikiran di sini memerlukan penguatan peraturan dari Menteri Pendidikan dan Kebudayaan.

\section{DAFTAR PUSTAKA}

Agung, I. (2013). CPD dan perubahan paradigma sekolah. Jurnal Pendidikan dan Kebudayaan, 19(2), Juni.

Agung, I. (2014). Pengaruh kompetensi sosial dan kepribadian terhadap kinerja guru. Jurnal VISI - UNJ, 9(2), 83-92.

Agung, I. (2014). Panduan penelitian tindakan kelas bagi guru. Jakarta: Zikrul Bestari.

Agung, I. (2017). Guru yang kompeten dan profesional: Orasi ilmiah profesor riset. Jakarta: Balitbang Kemendikbud.

Agung, I. (2018). Pengembangan keprofesian berkelanjutan (PKB) guru. Jakarta: Bee Media (akan beredar).

Barge. S. (2010). Principles of problem and project based learning: The aalborg PBL model. USA: Aalborg University.

Dalt, R. L. (2010). New era of management (era baru manajemen). Jakarta: Penerbit Salemba Empat.

De Graaf, E., \& Kolmos, A. (2003). Characteristics of problem-based learning. The International Journal of Engineering Education, 19(5), 657 - 662.

Ditjen GTK - Kemendikbud. (2015). Hasil UKG guru tahun 2015. Jakarta.

Ditjen GTK - Kemendikbud. (2016). Program guru pembelajar. Jakarta.

Ditjen GTK - Kemendikbud. (2017). Data hasil pre-test dan post-test pelatihan guru pembelajar. Jakarta.

Ditjen Anggaran Kementerian Keuangan. (2015). Kajian tunjangan profesi guru. Kanalinfo.web. id. Diakses dari https://www.kanalinfo.web. id/2016/03/tunjangan-profesi-guru.html)
Fiol, C. M. \& Marjorie, A.L. (1985). Organizational learning. Academy of Management Review, Oktober.

Hmelo, CE, Silver (2004). Problem based learning: What and how do student learn. Educational Psychology Review, 16(3), 235-266.

Lambros, A. (2004). Problem-based learning in middle and high school classrooms. CA: Corwin Press.

Leithwood, K., Leonard L., \& Sharratt, L. (1998). Conditions fostering organizational learning in schools. Educational Administration Quarterly, 34(2), 243.

Mangkunegara, A.A.A Prabu. (2010). Evaluasi kinerja SDM. Jakarta: Salemba Empat.

Marquardt, M.J. (1996). Building the learning organization. New York: McGraw-Hill.

Pedler, M. (1998). A concise guide to the learning organization. London: Publisher Lemos \& Crane.

Puslitjak. (2013). Hasil penelitian jam mengajar guru. Jakarta: Balitbang - Kemendikbud.

Robins, S.P, \& Judge, T.A. (1997). Organization behavior. New York: McGraw-Hill.

Rhem, J. (1998). Problem-based learning: An introduction, The National Teaching Learning Forum. 8(1), 1-7.

Senge, P.M. (1990). The fifth discipline the art and practice of the learning organization. New York: Doubleday.

Simatupang, B.M. (1995). ISO Seri 14000 dalam fokus organisasi belajar, manajemen \& usahawan Indonesia. Organisasi Belajar (Learning Organization), No. 11/Th.XXIV.

Watkin, K. E.\& Marsic, V.J. (1993). Sculpting the learning organization: Lessons in the art and science of systemic change. San Fransisco: Institue of Science Education. 